\title{
IMPLEMENTATION OF ISO 9001 AS A PREPARATION FOR IMPLEMENTING ISO 14001 IN SMALL-SCALE ENGINEERING COMPANIES
}

\author{
Dražen Kostelac, Mladen Vukomanović, Emil Priskić
}

Subject review

This paper analyses the implementation of quality management systems into small-scale engineering companies in Croatia. This paper attempts to account for the importance of implementation of an integrated quality system in accordance with ISO 9000 and an environmental management system in accordance with ISO 14001. The benefits of implementing the ISO 9001 norm as a preparation of introducing the ISO 14001 norm will be shown on the example of a small-scale engineering company. This paper emphasizes that it is precisely the periods in the process of acquiring ISO 9001, as well as the time necessary to collect the information and knowledge leading to a decision to enter into the process of ISO 14001 certification, that are potentially very significant for the company.

Keywords: engineering company; ISO 9001 and 14001 norms; quality control

Uvođenje ISO 9001 kao priprema za uvođenje norme ISO 14001 u male tvrtke inženjerske djelatnosti

Pregledni članak Rad analizira uvođenje sustava upravljanja kvalitetom u male tvrtke u Hrvatskoj koja obavljaju inženjersku djelatnost. Radom je ukazano na važnost uvođenja integriranog sustava kvalitete prema normi ISO 9000 i sustava upravljanja okolišem prema normi ISO 14001. Na primjeru male inženjerske tvrtke prikazat će se dobrobiti uvođenja sustava upravljanja kvalitetom sukladno zahtjevima norme ISO 9001. U ovom radu naglašava se da su upravo vremenski periodi procesa stjecanja certifikata ISO 9001, kao i vrijeme prikupljanja informacija i znanja koje vodi do odluke o tome da se kreće u proces ISO 14001 certifikacije, potencijalno vrlo značajni za tvrtku.

Ključne riječi: inženjerska djelatnost; konrola kvlitete; norme ISO 9001 i ISO 14001

\section{Introduction}

Today there is a large variety of quality norms developed for almost all areas of human activity. The quality, norms, series of norms and certificates are mentioned in terms of performance, competitiveness of companies, raising profits, creating added value and vice versa. Guidelines, instructions and tips proposed by norms aim to "lead" a company that wants to establish a quality system according to ISO 9001 up to the fulfillment of and compliance with the requirements that the company should adopt. Quality norms have evolved considerably from their origins to the present, but their potentials are still under-exploited. The opportunities for improvement exist in the introduction stage; preparatory activities, documentation and training in the stage after certification, when the company needs to continue to maintain high-quality business in an effort to optimize the same. Furthermore, there are possible improvements in the area of managing employees' potentials that participate in the establishment of the system quality of the company; managers, directors, employees, consultants, internal auditors.

The certificate of Quality Management System according to ISO 9001 enables companies to compete on the global market, or even shows as a necessary precondition for making new deals. For companies it is crucial to decide whether the certification as a formal, documented consequence of one impartial, authorized audit is cost-effective and necessary. For the introduction of a quality system according to ISO 9001, the strategies should be well-defined and a good knowledge of the market situation and trends in the given activity are required. The ISO 14000 norm is a kind of framework for the organization to apply their own good practice in environmental management in accordance with the legislation of the country in which they operate. This paper will first analyze the literature review about ISO 9001 and ISO 14001. Thereafter, the benefits of implementing the ISO 9001 norm as a preparation of introducing the ISO 14001 norm will be shown on the example of a small-scale engineering company.

\section{Literature review}

\subsection{Development and implementing of ISO 9001 norm}

Traces of the origin of ISO 9000 may be associated with the norms in the procurement of weapons around the Second World War. It was, with some changes, adopted in 1987 as ISO 9000 [1]. A minor revision was adopted in 1994, and the biggest change occurred in the revision of the year 2000. The last revision was made in 2008. The ISO 9000 family of norms represents an international consensus on recommended and good management practices and it is a general management norm. This means that the same norm could be applied to any businesses, small, medium or large-scale, to any activity and in any ownership structure. It is primarily intended for quality management, i.e. it focuses on what the company does to ensure the products in accordance with customer requirements. Although it does not guarantee the quality, the ISO 9001 certificate means that an independent auditor has checked the processes that affect the quality [2].

Criticism about the initial version of the ISO 9001 series of norms was directed to the fact that the important items of quality have been scattered and unconnected within the documents [2]. It was also said that the concepts of TQM were not applied while introducing the requirements [3]. Thus, the second revision in 2000 was 
very important, linking the norms and the requirements with the recognized and efficient techniques and practices to enable continuous improvement in all aspects of the company. However, the aspect of how to do something, to implement and measure it is still an area that requires knowledge and continuous improvement of those in charge of implementing the quality of the wider area of the ISO norms documentation [4].

ISO 9001:2008 explains in a more detailed way the items of the previous version norm for better application of requirements. It is very detailed, containing the full documentation system that allows companies daily monitoring operations, not only in order to meet user requirements, but it encourages a process of continuous improvement of products and services, in order to exceed customer expectations. This creates a powerful combination of documentation, along with a large number of continuous improvement approaches, such as internal audits of quality, systems of preventive and corrective actions, data analysis and others. Understanding all potential norms and effective implementation enables to achieve long-term benefits from certification.

However, the same authors [5] emphasize that the areas of quantifying the performance are poorly researched, as well as measuring the performance of employees.

Performance measuring based on scientific analysis enables accurate, well-designed information that is essential in the process of decision making and management. In the past 30 years performance measuring has outdistanced considering only financial factors to combined factors, which include as well the non-financial ones, such as operations, processes, products, quality, safety, employees, customer satisfaction, etc. Certification authorities emphasize the benefits that the company receives by certifiying the quality management system, e.g. ANAB, a leading ISO 9001 accreditation board in the United States refers to the 16 benefits of certification, including increased operational efficiency, lower costs due to reduced processing, customer satisfaction, competitive advantage, the perception of better quality and increased market share. In Europe very similar conclusions have been adopted by the leading accreditation boards in collaboration with some scientific surveys [6].

The introduction of quality management system based on ISO 9001 increases the managerial ability to control processes through their formalization [7]. The arguments in favor of the introduction of ISO 9001 are the following: increased efficiency [5], increased operations control [8], enhanced production efficiency. Reducing information asymmetry [9] is often stated as a proof of the benefits of introducing ISO 9001. The research [10] shows that ISO 9001 certificate improves customer perceptions related to quality, satisfaction and the company's image.

The research [11] about the certification benefits taking the explanatory variables: the focus on domestic or foreign markets, management experience, company's size, geographic distribution, type of ownership and location. The data used in this research were taken from the World Bank's Enterprise Surveys sample of 11,668 companies in Central and Eastern Europe and Asia. Among other things, it can be seen that the number of certified companies in the EU countries is high, except in Poland and the Baltic states, where it is low. The survey showed that the vast majority of them referred to ISO 9001 and/or ISO 14001. The whole process around the introduction of ISO 9001 and ISO 14001 or others is similar to the process of graduation and possession of a diploma as a certificate [12].

Other authors in their researches [13] point to the often insufficient understanding of the philosophy of quality managing the audits of quality. The authors believe that auditors pay more attention to whether the customer's quality system is effectively documented, and little attention is paid to the consequences of the quality system.

Poor auditors question the whole process of audits and the credibility of the ISO 9001 certificate.

The question that arises is how to add value to the audit process? Besides the fact that the approach to the added value is associated with the existing climate of quality in the company, it emphasizes the role of auditors who should, as experts, help the company to improve quality and efficiency [14]. They are responsible for performing audits that improve processes while realizing managerial objectives, too. Such an important role of the auditors represents a significant departure in thinking about the auditor as a strict, rigid and inflexible and about the progress of audits as stressful, hostile and barren for team collaboration, problem solving and proactive improvement, but not all types of audits are open to this kind of understanding. There are three types of audits: internal audits, audits of clients/customers and externalimpartial audits. Internal audits are conducted within the company and are held by company employees. The internal audit is defined as "an independent, objective activity designed to add value and improve the operations of the company. It helps the company to achieve its objectives by bringing a systematic, disciplined approach to evaluate and improve the effectiveness of risk management, control of processes" [15].

Another type of audits, in the literature cited as a second-party audit, is usually carried out by the client/customer in businesses of its suppliers to ensure that the supplier meets contractual requirements. The third type of audit, external or third-party audit shall be conducted for the purpose of certification, and run by an authorized certification company. This is an estimate of the company's quality system, and run by independent auditors of a certification company (e.g. the ISO 9001 quality management system is subject to this type of audit). The consultant should also actively communicate with employees at all times in order to jointly find the optimal solution and the optimal way of developing after the process, so it is necessary to inform about the efforts of the quality system or even educate specific personnel who will be involved in the process of introducing the quality system. The objective of implementing ISO 9001 for the company $[16]$ :

The certificate ISO 9001 indicates that the company operates fulfilling the requirements prescribed by the norm. In the process of creating a product or service, a company that meets the ISO 9001 norm should take account of employee's satisfaction, partners, customers, 
should strive to constantly improve all processes by minimizing all surpluses and costs, which should lead to competitive products and services and increasing profits. Such claims are potentially correct only in the event that the company's leadership understands how to operate in accordance with the requirements and guidelines even after certification, and if they take action necessary for constant improvements at all levels in the company. The certificate does not provide continuous improvement, but it is up to the people in the company in charge of quality. The ISO 14001 norm also requires that the audit and procedures cover the monitored activities and areas, their frequency, the responsibilities associated with managing and conducting audits, results demonstration, the competence of auditors and the manner of its implementation and upgrades to the ISO 9001 norm. Today it is common to integrate the quality management system and the environmental management system.

\subsection{Development and implementing of IS014001 norm}

The environmental management system is the system by which organizations improve their performance by minimizing the environmental impact. It is being generated with the control of environmental aspects that have a harmful effect on the environment.

Intensive economic and social development with uncontrolled negative impact on the environment (waste product), destruction of natural resources, uncontrolled demographic growth, the consequences of armed conflict in which modern means of combat are used, drought and adverse weather conditions, volcanic eruption and fall of foreign bodies (asteroids, meteors, meteorites, comets, etc.) on Earth are the main prime movers in developing the environmental awareness and environmental policy at the global level [18].

The need for a systematic resolution of harmful effects has been imposed. Many countries have proposed the basic elements of such an environmental management system (Environmental Management System - EMS) and the norm to measure the effectiveness of these systems. Today, in the management of environmental protection there are two recognized worldwide norms: the international norm ISO 14001 and the European scheme for eco-management and audit (European EcoManagement and Audit Scheme - EMAS), which also is applied to the European Union members. It is important to note that these norms are voluntary, i.e. there is no legal obligation for their implementation. Despite that, there is an increasing number of enterprises that apply them, because they acquire a number of advantages thus, and they especially strengthen competitiveness and their position in the market [19].

The first ISO 14001 norm was published in 1996 entitled "Environmental management systems Specification with guidance for use", and is one of the ISO 14000 series of norms that specify requirements for the proper management of the environment. This norm helps companies to protect the environment, preventing pollution and achieving compliance with social and economic needs. The currently valid norm is ISO 14001: 2004 [20].

The EMAS is a voluntary environmental management scheme for organizations operating in the European Union to promote the continuous improvement of environmental indicators of organizations. The European Commission promotes the EMAS as a strong and structured tool [20]. The EMAS, therefore, can have a binding approach to the environment because it is embedded in the law and regulations of the member states of the European Union. One of the most important differences is that the EMAS was at that time used only in the manufacturing industry and it certainly proved the pilot schemes, while at the same time, ISO norms suit to any type of organization, even those that are not considered businesses, e.g. government offices. This has largely bridged the gap between the ISO 14000 and the EMAS and created the basis that they "integrate". Based on the interpretation of ISO 14001 it can be concluded that the main requirement of the norm is to constantly improve the relationship with the environment. The socalled Deming's PDCA circle [21] is embedded in the concept. The ISO 14001 norm [22] contains no specific requirements of other management systems such as quality management, occupational health and safety, financial resources, risk, etc. Still, this norm enables an organization to personalize their own environmental management system with adequate requirements of other management systems. form:

The structure of the ISO 14001 has the following

1. Application area

2. Reference to other norms

3. Terms and definitions

4. Requirements of the environmental management system

5. General requirements

6. Environmental policy

7. Planning

8. Introduction and operation

9. Verification and education

10. Rating system

Fig. 1 shows the number of certificates issued in accordance with the ISO 14001 norm.

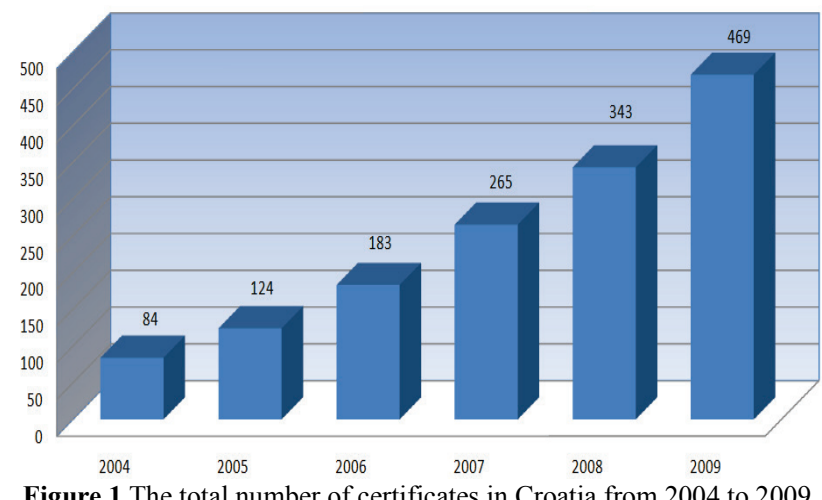

Figure 1 The total number of certificates in Croatia from 2004 to 2009 [15]

The number of certificates issued in accordance with ISO 14001 is increasing every year. Tab. 1 shows the number of certificates issued according to the NACE division of industrial branches. The engineering services are in the middle of the table, which is satisfactory in 
view of the potential pollution of the branches below them in Tab. 1.

Statistical data about the number of certificates issued according to ISO 14001 in some European countries are shown in Fig. 4. Statistical data were obtained in the journal ISO Survey - 2008 [1]. According to the number of certificates issued, Croatia lags behind European countries. By December 2008, Croatia had issued 343 certificates, Slovenia 444, Austria 837, Hungary 1834, Italy 12 922, etc.

Table 1 Ten most common industrial sectors as per number of certificates issued according to ISO 14001 [16]

\begin{tabular}{|l|c|c|}
\hline \multicolumn{1}{|c|}{ Industrial sector } & NACE & $\begin{array}{c}\text { Number of } \\
\text { issued } \\
\text { certificates }\end{array}$ \\
\hline Construction & 28 & 66 \\
\hline Other services & 35 & 41 \\
\hline Manufacture of basic metals and metal & 17 & 35 \\
\hline $\begin{array}{l}\text { Wholesale and retail trade; repair of } \\
\text { motor vehicles, motorcycles and } \\
\text { personal and household appliances } \\
\text { products }\end{array}$ & 29 & 33 \\
\hline $\begin{array}{l}\text { Manufacture of electrical and optical } \\
\text { equipment }\end{array}$ & 19 & 32 \\
\hline Other public services & 39 & 27 \\
\hline Engineering services & 34 & 24 \\
\hline $\begin{array}{l}\text { Manufacture of concrete, cement, lime } \\
\text { and plaster }\end{array}$ & 16 & 21 \\
\hline Manufacture of rubber and plastic & 14 & 20 \\
\hline $\begin{array}{l}\text { Manufacture of machinery and } \\
\text { equipment }\end{array}$ & 18 & 19 \\
\hline Other sectors & 151 \\
\hline
\end{tabular}

However, it can be seen that the number of certificates issued in Croatia is on the rise every year. The highest number of certificates issued was recorded in the construction sector with a share of $14,07 \%$, while the sector of engineering services achieved a share of 5,12\% of the total number of certificates issued.

\section{Implementation of ISO 9001 documentations in the enginnering company Novatec Ltd. - case study 3.1 About Novatec Ltd. Labin}

Novatec is a software development company. Novatec has been established to focus on the mining and minerals sector, bringing 20 years of experience in industrial automation processes.

\subsection{The phases of the project}

The project was developed through the following phases lasting from 2012 to 2013:

$1^{\text {st }}$ phase: spotting problems and orientation related problems. There has been an issue in disconnected process and workflow documentation in the engineering company Novatec Ltd. It was decided that Novatec would start a project of implementing the ISO 9001 norms.

$2^{\text {nd }}$ phase: defining the problem. The key processes were defined as well as the responsibility of the Head of Department for the preparation of implementation of the ISO 9001 norm.

$3^{\text {rd }}$ phase: snapshot of the current situation. Before the snapshot of the current situation an external consultant, a quality manager and a team for implementing the norms had been selected.

$4^{\text {th }}$ phase: training of employees. The training of internal auditors was conducted by an external consultant, while several workshops trained all employees of the company with the processes and documentation of the ISO 9001 norms.

$5^{\text {th }}$ phase: preparing documentation for the quality management system (QMS) ISO 9001. The preparation of the QMS documentation required the highest participation of the external consultant, the quality manager and the head of departments.

$6^{\text {th }}$ phase: implementation of procedures and instructions. Prepared procedures and instructions were presented to employees and were adopted before the internal audit.

$7^{\text {th }}$ phase: internal audit and review system that management performs. Internal audits within departments were carried out in two working days with the help of an external consultant and the quality manager.

$8^{\text {th }}$ phase: elimination of non-compliance. All heads of departments were given a deadline of seven days for the correction of non-compliance that were observed in the project documentation in the individual work procedures .

$9^{\text {th }}$ phase: certification of quality control systems. The quality system certification in Novatec was carried out by one of the authorized certification companies and all documents, as well as the oral examination of staff have been completed successfully.

$10^{\text {th }}$ phase: improving the system. Both the guidelines and deadlines were given for improving the system until the next re-certification, which is conducted yearly.

The first four stages were carried out over a period of four months with the help of an external consultant. The representatives of the Administration for quality, critical processes and employees training plan were defined.

The next phases of the project:

In the process of implementation the $5^{\text {th }}$ and $6^{\text {th }}$ phases have proven to be critical in terms of time used by external and internal resources.

Below, there are some documents adopted by the Board of Novatec Ltd.:

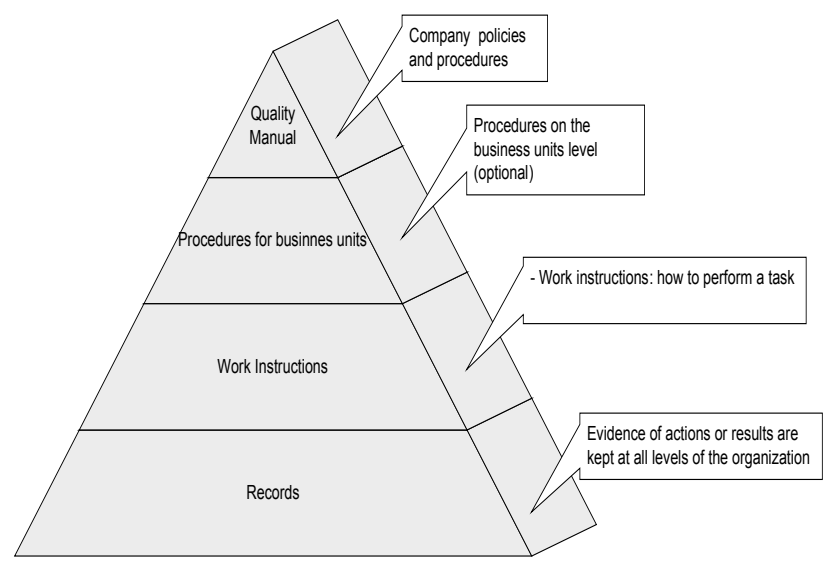

Figure 2 ISO 9001 Novatec d.o.o documentations

Basic ISO 9001 documentation contents, Fig. 2:

- A filed statement of policy and quality objectives.

- Quality Manual - a document for internal and external 
needs provides information on the methods and the application of the quality management system.

- Documented business processes and working practices

- Documents that provide information about the types, mode and course of performance of certain activities in the carrying out of specific services.

- Quality Records - documents that contain information and evidence about the activities carried out and the results that were obtained with the implementation of the quality management system.

\section{Procedures and work instructions: Novatec Ltd. NP projects - HW Design Planning and Controlling}

The project design planning and control assures that each design and development activity is planned, documented, and controlled. The design planning and control assures that planning of the different phases used to carry out the design and development, addresses the organization, significant stages, and method of configuration control. The input data specific to each element is reviewed to ensure consistency with requirements. The design planning and control assures that the different design and development tasks are defined according to specified safety or functional objectives of the product in accordance with customer and/or regulatory authority requirements.

Purpose of this phase is to produce requested documentation according to Project requirements by actually completing Technical documentations (I/O list, drawing layouts of control stations and automation cabinets, incoming line calculations, single line diagrams), drawing electrical schematic, making Bill of material. Scope of deliverables depends on the complexity of the project, and is defined in the project requirement document, Fig. 3.

Work starts from Project requirement spreadsheet and General electric data, that contains all project basic data like:

- environmental data

- general norms

- electrical power supply data at point of common coupling

- $\quad$ electrical equipment technical data

- automation equipment technical data

- $\quad$ system engineering and maintenance tools

- network technical characteristics.

This document can be received from client or can be created in the planning phase. It shows what equipment must be used for automation:

PLC type, distributed I/O station type, communication network type, norms for component designation and cable designation, software tools for drawings and documentation, etc. All drawings, specifications, diagrams produced in order to satisfy clients requirements are stored by means of SVN software under repository 1 DESIGN.

Automation \& network block diagram where entire project is shown. That document contains all equipment, switchboards and their interconnections. For simple projects, this document is not created due to the non existence or simple network topology, in which case it forms part of the main electrical machines. If it is not supplied (revamping or simple projects) it can be developed during design phase. Motors \& sensors list is a document that contains all electrical equipment that is installed in project and the way how it must be controlled by automation and electrical system in project.

For simple projects it can be avoided, so the I/O list or drawings are designed directly from old documentation or customer input data.

Local control stations are part of electrical equipment used for machine or process control. They are designed based on 'in house" know-how of technological process, or can be designed in collaboration with customer.

For simple projects, this document forms part of the input/output cards. PLC cards configurations and PLC main electrical drawings. Emergency panels (machine safety stop features) are designed in accordance with safety norms. If requested by client, relevant document can be produced: Emergency panel technical specification. That document contain list of all motors and actuators which have to be stopped with correspondent emergency stop circuit. It also shows all contacts distribution to relevant equipment such are MCC 's (motor control centers), PLC's, remote I/O's and other external equipment (packages). For a small project it can be part of automation switchboard, and Emergency panel technical specification is not produced, as well, the emergency panel sistem forms part of the main electrical drawings.

Automation Electrical Drawings detail design. I/O list can be produced for complex project. This document is Excel spreadsheet which is used to configure PLC system. It contains the list of all input and output signals (digital and analog).

During design it is necessary to pay attention to logical and physical limitation of PLC structures (not to exceed limits).

I/O list can be avoided for simple project, so automation electrical drawings can be designed directly from $\mathrm{M} \& \mathrm{C}$ list or customer specifications.

Power switchboards technical specification for Motor Control Center (MCC) and drives switchboards is based on Motor \& sensors list using typical solutions for different starter types. Incoming line main circuit breaker size is defined inside dedicated spreadsheet.

Single line diagram is also part of this technical specification. This specification will be used as base for creation of Power switchboards Electrical Drawings detail design.

Detail electrical drawings are functionally oriented: one set contains sheets that make one functional technologically defined unit.

Supervision switchboards technical specification is a document which describes supervision system parts and network elements. IT Devices data sheets are part of this specification.

This specification will be used as base for creation of Supervision Switchboards Electrical Drawings detail design. For simple projects, specification is not created, instead, electrical drawings detail design is created directly, or even can form part of main electrical drawings. Bill of material, that will be used for material 
purchase orders, is generated as part of detail electrical drawings. After assembling it is necessary to perform testing of electrical equipment according to Electrical equipment test procedure. Result is Electrical equipment test report and collection of certificates for installed components and equipment.

Test should be approved by Head of HW Department. When contract requests customer presence at HW assembly testing, customer should sign test reports.

If switchboards are part of delivery to customer (defined in contract and project requirements) purchase of material is done according to bill of material by Purchase department.

All offers from suppliers and placed orders to suppliers are gathered in "3_ORD" directory.

Inputs are: Project Plan, Specification, Project Input Data Collection, General Electric data, Automation \& Network block diagram, Documents Requirement, Basic Functional Specification

Outputs are: Technical specifications, Electrical drawings, Bill of material, Electrical equipment switchboards and test reports.

\section{HW DESIGN}

INPUTS : PROJECT REQUIERMENTS GENERAL ELCTRIC DATA , AUTOMATION \& NETWORK DIGRAMS, MOTORS \& SENSORS LIST,BASIC FUNCTIONAL SPECIFICATION , CUSTOMER DATA

OUTPUTS : PROJECT DOCUMENTATIONS (TECHNICAL SPECIFICATION, IT DEVICES DATASHEET, ELECTRICAL DRAWINGS, NETWORK DIAGRAMS, SWITCHBOARD

LAYOUTS ), BILL OF MATERIAL AND EQUIPMENT, SWITCHBOARDS ASSEMBLING

QUALITY RECORDS : CHECK LIST HW DESIGN VERIFICATION, TEST REPORT FOR ELECTRICAL EQUIPMENT

HOW IS PROCESS CONTROLED : THROUGH MANTIS TASK MANAGEMENT AND TASK STATUS SPREADSHEET, SVN REPOSITORY

WHAT IS MEASURE : WORKING EFFORT -WORKING HOUR, FEEDBACK FROM COMISSIONING : AMOUNT OF MODIFICATIONS AT COMISSIONING

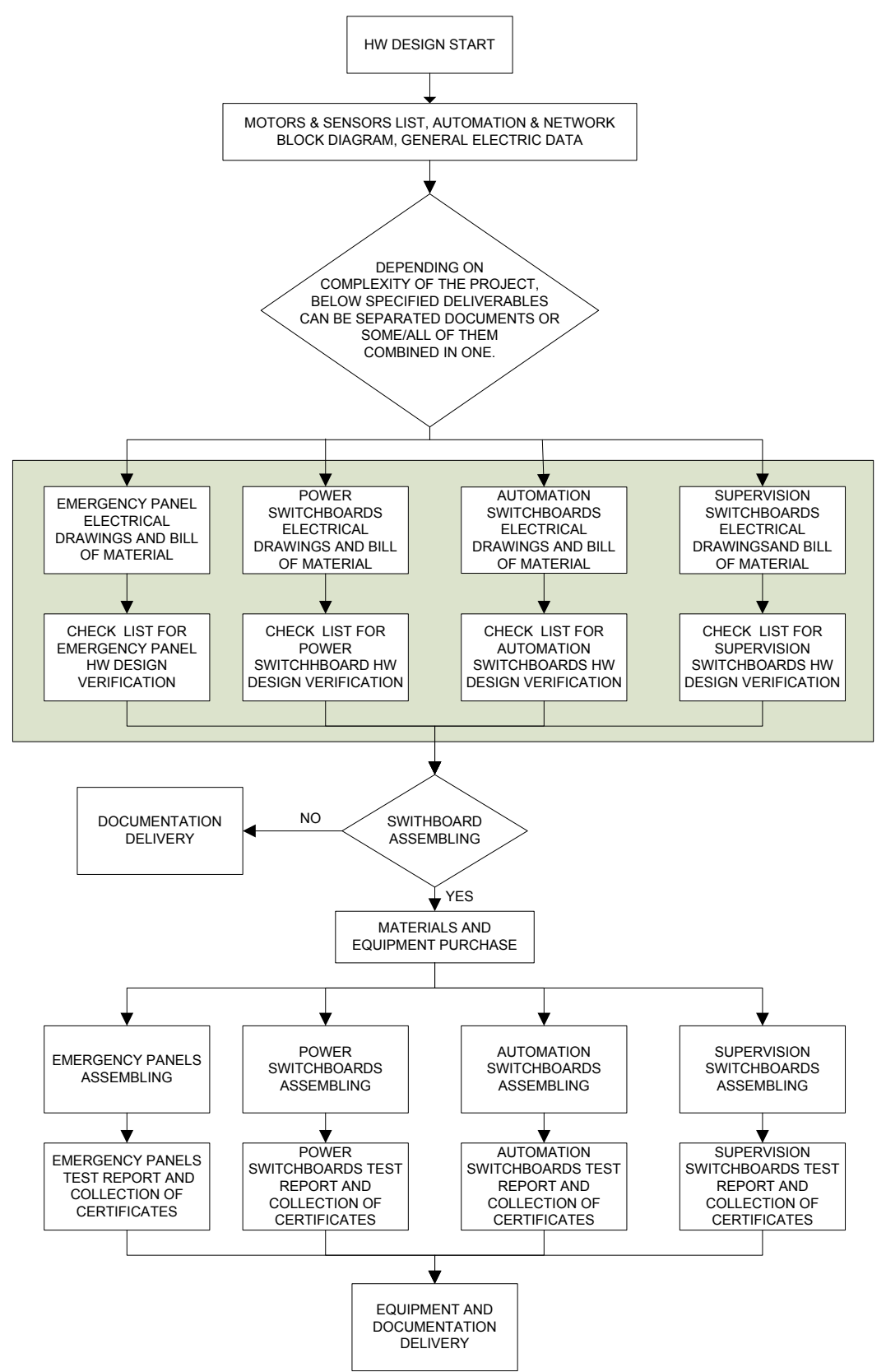

Figure 3 HW Design flow chart diagram
After development is completed, verification, in which basic project elements conformity with client's requests are checked, needs to be completed.

Result of verifications and validations is reported is HARDWARE DESIGN VERIFICATION TEST REPORT sheet. HW design testing procedure is described in separate documents: HW DESIGN TEST_PROCEDURE.
Test should be approved by Head of HW Department. When contract requests customer presence at HW design testing, customer should sign test reports.

When electrical switchboards are scope of supply it is necessary to assemble and wire electrical components and equipment in switchboards and local control stations according to electrical drawings and bill of material. If 
any modification has been made during electrical switchboard assembly, the changes will be updated to drawings, and as manufactured revision of drawings will be saved to "ELECTRICAL SWITCHBOARD AS MANUFACTURED".

\section{Preparation of the project of implementing the ISO 14001 norm}

The next step in the implementation of QMS is the integration of the ISO 14000 and ISO 9001 norms in Novatec Ltd. during the 2015:

The project was planned in stages as ISO 9000 with less effort put by the internal resources:

Pre-project phase:

Acceptance of environmental awareness, fulfillment of environmental tasks and commitment to obtain certification according to ISO 14001 starts from the management of Novatec Ltd.

According to the ISO 14000 norm, the company should document the entire EMS process from establishing environmental objectives to achieving results by displaying procedures, work instructions, processes and other records. The efficient and effective implementation of the requirements of ISO 14001 in the existing ISO 9001 quality management norm can be carried out as follows:

All documents are based on the documentation of the ISO 9001 norm. Since the documents have already been described in the previous chapter in the phases 5 and 6 , the introduction of the project ISO 14001 was therefore speeded up considerably.

Thus, the preparation for the implementation of ISO 14001 is more efficient from the practical viewpoint of a small-scale engineering company Novatec Ltd.

This paper emphasizes that it is precisely the periods in the process of acquiring the ISO 9001, as well as the time necessary to collect the information and knowledge that lead to a decision to enter into the process of the ISO 14001 certification, potentially very significant for the company.

This is the period when the entire business starts to be put into question, when different problems are detected, the alternatives to improve are listed, plans for the future of the company are created. It is precisely through these processes that the company as a whole changes for the better.

Execution of the project:

Duration: 5 months

Budget: 15000 euros

Project Team: Management, Quality Manager, Heads of Departments, ISO 14001 Consultant

Project risks: time limit, limited inner resources of a small-scale engineering company, documentation non compliant to ISO 9001 documentation

Benefits of environmental management for Company:

- cost savings from greater attention to process efficiency, waste reduction, materials and energy use

- meeting customer requirements

- generating competitive advantage

- more efficient and cost effective regulatory compliance, including avoiding prosecution or costly

- $\quad$ shut down/planning delays
- improved community relations/“license to operate’

- avoid unwelcome attention from pressure groups/media

- $\quad$ potentially more attractive to investors/shareholders

- better access to bank loans/insurance

- may make the company more attractive to good recruits and enhance pride and productivity amongst existing.

\section{Conclusion}

Companies that called a halt to develop a strategy of quality business after obtaining certification were considerably behind the times, the financial aspect and the quality of performance. The ISO 9001 norm is an important starting point for the development of TQM strategy as well as achieving significantly better business results. Given that the process of introducing the quality system is sometimes time-consuming and requires the services of consultants that are expensive, an accountable and well-informed management is crucial, and basing on the current state of the company, the available resources and evaluation of the consultants, they decide on at least rough length of time necessary to introduce the quality system.

Finally, both norms require that organizations determine the potential impact of quality and ecology in their business processes. Regardless of many potential benefits, companies are aware that the transition to ISO 9001 is very demanding, and often time-consuming and expensive. Notwithstanding, the example of this smallscale engineering company proves the following views and opinions about the ISO 9001 and ISO 14001 upgrade: To achieve business conditions that enable a long-term successful business it is necessary to be acquainted with the basic concepts of TQM. For companies, ISO 9001 (from the second audit onwards) is suitable for creating and developing TQM spirit and thinking in this direction and in this way.

The benefits of establishing a quality system according to ISO 9001, and the guidelines for maximizing the potential in phases before and after certification.

The ISO 9001 norm of quality control and the ISO 14001 environmental norms have plenty in common:

1. The objectives and mission of the company.

2. Registration processes for ISO 9001 and ISO 14001 are similar in the way they require audit by a third party to verify compliance with the norms.

3. Both norms provide sufficient flexibility so as to conform with the needs of the organization. Finally, both norms require that organizations determine the potential impact of quality and ecology in their business processes.

\section{References}

[1] ISO Survey Certifications 2008, ISO Central Secretariat, Switzerland, 2009, http://www.iso.org

[2] Terziovski, M. et al. The longitudinal effects of the ISO 9000 certification process on business performance. // European Journal of Operational Research. 146, 3(2003), pp. 580-595. DOI: 10.1016/S0377-2217(02)00252-7

[3] Rezaee, Z. Emerging ISO 14000 environmental norms: a step-by-step implementation guide. // Managerial Auditing 
Journal. $\quad 15, \quad 1 / 2(2000), \quad$ pp. $\quad 60-67$ DOI: $10.1108 / 02686900010304650$

[4] El Tigani, O. For a Brighter ISO 9001:2008 Certification. // The Journal for Quality \& Participation. 35, 3(2012), special section $\mathrm{p} 1$.

[5] Priručnik za društveno odgovorno poslovanje, okoliš, ulažite u buduće generacije, UNDP, Zagreb, 2005.

[6] Gavin, P. M. D. Exploring performance attribution. // International Journal of Productivity and Performance Management. 58, 4(2009), pp. 311-328. DOl: 10.1108/17410400910950991

[7] Beck, N.; Walgenbach, P. Technical efficiency or adaptation to institutionalized expectations? The adoption of ISO 9000 norms in the German mechanical engineering industry. // Organization Studies. 26, 6(2005), pp. 841-866. DOl: 10.1177/0170840605054599

[8] Gotzamani, K. D.; Tsiotras, G. D. The true motives behind ISO 9000 certification: their effect on the overall certification benefits and long term contribution towards TQM. // International Journal of Quality \& Reliability Management. 19, 2(2002), pp. 151-169. DOI: $10.1108 / 02656710210413499$

[9] Bhuiyan, N.; Alam, N. An investigation into issues related to the latest version of ISO 9000. // Total Quality Management. 16, 2(2005), pp. 199-213. DOl: 10.1080/14783360500054343

[10] Nicolau, J. L.; Sellers, R. The quality of quality awards: Diminishing information asymmetries in a hotel chain. // Journal of Business Research. 63, 8(2010), pp. 832-839. DOI: 10.1016/j.jbusres.2009.06.009

[11] Caro, L. M.; Garcia, J. A. M. Does ISO 9000 certification affect consumer perceptions of the service provider? // Managing Service Quality. 19, 2(2009), pp. 140-161. DOl: 10.1108/09604520910943152

[12] Valmohammadi, C.; Khodapanahi, M. The impact of ISO 9001:2000 implementation on employees' job satisfaction: a case study. // International journal of academic research. 3, 1(2011).

[13] Hudson, J.; Orviska, M. Firms' adoption of international standards: One size fits all? // Journal of Policy Modeling, Elsevier, vol. 35, 2(2013), pp. 289-306. DOI: 10.1016/j.jpolmod.2012.04.001

[14] Dereli, T. et al. Fuzzy quality-team formation for value added auditing: A case study. // Journal of Engineering and Technology Management. 24, 4(2007) pp. 366-394. DOl: 10.1016/j.jengtecman.2007.09.005

[15] Hutchins, G. ISO 9000: A Comprehensive Guide to Registration, Audit Guidelines and Successful Certification. Oliver Wight Publications Inc., Essex Junction, Vermont, 1993.

[16] HR Survey 2009, Hrvatsko društvo za kvalitetu, Osijek, lipanj 2009., http://www.kvaliteta.net

[17] Najmi, M.; Kehoe, D. F. An integrated framework for postISO 9000 quality evelopment. // International Journal of Quality and Reliability Management. 17, 3(2000), pp. 226258. DOI: 10.1108/02656710010300117

[18] Sustav upravljanja zaštitom okoliša - Norma ISO 14001

[19] Terlaak, A.; King, A. A. The effect of certification with the ISO 9000 Quality Management Norm: A signaling approach. // J. of Economic Behavior \& Org. 60, 4(2006), pp. 579-602. DOI: 10.1016/j.jebo.2004.09.012

[20] Naveh, E. et al. ISO 9000 survey '99: An Analytical Tool to Assess the Costs, Benefits and Savings of ISO 9000 Registration. MacGraw-Hill, New York San Francisco, Washington, DC, (1999), p. 274.

[21] Bešker, M. Politika okoliša, I. dio, Oskar, Centar za razvoj i kvalitetu, Zagreb, 2005.

[22] Črnjar, M.; Črnjar, K. Menadžment održivog razvoja, ekonomija, ekologija, zaštita okoliša, Sveučilište u Rijeci, Rijeka, 2009.

\section{Authors' addresses}

Dražen Kostelac, Ph.D

Business Academy PAR

Trg Riječke rezolucije 4, 51000 Rijeka, Croatia

E-mail: drazen.kostelac@par.hr

Mladen Vukomanović, Assistant Professor

University of Zagreb, Faculty of Civil Engineering, Kaciceva 26, 10000 Zagreb, Croatia

e-mail: mvukoman@grad.hr

\section{Emil Priskić, Ph.D}

EPO - Business Consulting

Radnička cesta 2, 51410 Opatija, Croatia

E-mail: e.priskic@gmail.com 